\title{
Threonine 149 Phosphorylation Enhances $\Delta$ FosB Transcriptional Activity to Control Psychomotor Responses to Cocaine
}

\author{
Hannah M. Cates, ${ }^{1}$ Mackenzie Thibault, ${ }^{2}$ Madeline Pfau, ${ }^{1}$ EElizabeth Heller, ${ }^{1}{ }^{\circledR}$ Andrew Eagle, ${ }^{2}$ Paula Gajewski, ${ }^{2}$ \\ Rosemary Bagot, ${ }^{1}$ Christopher Colangelo, ${ }^{4}$ Thomas Abbott, ${ }^{4}$ Gabby Rudenko, ${ }^{3}$ Rachael Neve, ${ }^{5}$ Eric J. Nestler, ${ }^{1}$ \\ and Alfred J. Robison ${ }^{2}$ \\ ${ }^{1}$ Fishberg Department of Neuroscience and Friedman Brain Institute, Icahn School of Medicine at Mount Sinai, New York, New York 10029, ${ }^{2}$ Department of \\ Physiology, Michigan State University, Lansing, Michigan 48824, ${ }^{3}$ Department of Pharmacology/Sealy Center for Structural Biology and Molecular \\ Biophysics, University of Texas Medical Branch, Galveston, Texas 77555, ${ }_{4}^{4}$ Department of Molecular Biophysics and Biochemistry/Keck Biotechnology \\ Services, New Haven, Connecticut 06511, and ${ }^{5}$ Department of Brain and Cognitive Sciences, Massachusetts Institute of Technology, Cambridge, \\ Massachusetts 02139
}

Stable changes in neuronal gene expression have been studied as mediators of addicted states. Of particular interest is the transcription factor $\Delta$ FosB, a truncated and stable FosB gene product whose expression in nucleus accumbens (NAc), a key reward region, is induced by chronic exposure to virtually all drugs of abuse and regulates their psychomotor and rewarding effects. Phosphorylation at Ser ${ }^{27}$ contributes to $\Delta$ FosB's stability and accumulation following repeated exposure to drugs, and our recent work demonstrates that the protein kinase CaMKII $\alpha$ phosphorylates $\Delta$ FosB at $\operatorname{Ser}^{27}$ and regulates its stability in vivo. Here, we identify two additional sites on $\Delta$ FosB that are phosphorylated in vitro by CaMKII $\alpha$, Thr ${ }^{149}$ and $\mathrm{Thr}^{180}$, and demonstrate their regulation in vivo by chronic cocaine. We show that phosphomimetic mutation of $\mathrm{Thr}^{149}$ (T149D) dramatically increases AP-1 transcriptional activity while alanine mutation does not affect transcriptional activity when compared with wild-type (WT) $\Delta$ FosB. Using in vivo viral-mediated gene transfer of $\Delta$ FosB-T149D or $\Delta$ FosB-T149A in mouse NAc, we determined that overexpression of $\Delta$ FosB-T149D in NAc leads to greater locomotor activity in response to an initial low dose of cocaine than does WT $\Delta$ FosB, while overexpression of $\Delta$ FosB-T149A does not produce the psychomotor sensitization to chronic low-dose cocaine seen after overexpression of WT $\Delta$ FosB and abrogates the sensitization seen in control animals at higher cocaine doses. We further demonstrate that mutation of Thr ${ }^{149}$ does not affect the stability of $\Delta$ FosB overexpressed in mouse NAc, suggesting that the behavioral effects of these mutations are driven by their altered transcriptional properties.

Key words: accumbens; CaMKII; cocaine; $\delta$ FosB; phosphorylation; transcription

\section{Introduction}

Drug addiction arises in part from altered gene expression in discrete brain regions in response to chronic exposure to drugs of abuse (Robison and Nestler, 2011). Increasing evidence suggests that a subset of these gene expression changes are mediated by $\Delta$ FosB, a Fos family transcription factor induced in multiple brain regions specifically by chronic exposure to virtually all drugs of abuse (Nestler, 2008; Perrotti et al., 2008). In nucleus

\footnotetext{
Received April 21, 2014; revised June 23, 2014; accepted July 15, 2014.

Author contributions: E.J.N. and A.J.R. designed research; H.M.C., M.T., M.P., E.H., A.E., P.G., R.B., C.C., T.A., and A.J.R. performed research; G.R. and R.N. contributed unpublished reagents/analytic tools; H.M.C., C.C., T.A., and A.J.R. analyzed data; H.M.C. and A.J.R. wrote the paper.

This work was supported by the National Institute on Drug Abuse (NIDA; E.J.N.), NIDA-Yale Proteomics Center Grant DA018343 (A.J.R. and E.J.N.), the National Institute of Mental Health (G.R.), the Brain and Behavior Research Foundation (G.R.), and the Whitehall Foundation (A.J.R.)

The authors declare no competing financial interests.

Correspondence should be addressed to A.J. Robison, PhD, Department of Physiology, Michigan State University, 567 Wilson Road, Room 3180, East Lansing, Ml 48824. E-mail: robis045@msu.edu.

DOI:10.1523/JNEUROSCI.1611-14.2014

Copyright $\odot 2014$ the authors $\quad 0270-6474 / 14 / 3411461-09 \$ 15.00 / 0$
}

accumbens (NAc), $\Delta$ FosB expression increases locomotor and rewarding responses to drugs of abuse (Kelz et al., 1999; Colby et al., 2003), whereas blockade of $\Delta$ FosB transcriptional activity reduces drug reward (McClung and Nestler, 2003; Peakman et al., 2003; Zachariou et al., 2006; Robison et al., 2013). NAc $\Delta$ FosB also regulates other forms of reward. It accumulates in NAc with sexual experience, sugar and high-fat diets, and calorie restriction, and promotes reward to these stimuli (Pitchers et al., 2010, 2013; Been et al., 2013). Additionally, NAc $\Delta$ FosB is induced by chronic stress and antidepressant treatment and mediates stress resilience and antidepressant action (Vialou et al., 2010; Robison et al., 2014).

These effects are mediated by numerous $\Delta$ FosB gene targets (McClung and Nestler, 2003). Recent work has focused on $\Delta$ FosB induction of CaMKII $\alpha$, which is specific to D1-type medium spiny neurons (MSNs) of NAc shell and mediates $\Delta$ FosB's enhanced responses to cocaine and antidepressant-like actions (Robison et al., 2013, 2014). NAc CaMKII regulates the psychomotor effects of cocaine through AMPA receptor modulation (Pierce et al., 1998), and recent work demonstrates that $\Delta \mathrm{FosB}$ 
regulates NAc MSN glutamatergic synapse morphology and function in a cell type-specific manner (Grueter et al., 2013), a process long associated with the structural and catalytic roles of CaMKII (Hell, 2014).

$\Delta$ FosB not only regulates CaMKII expression, it is also phosphorylated by CaMKII, establishing a feedforward loop engaged by chronic cocaine that is essential for cocaine's behavioral and cellular effects (Robison et al., 2013). Previous studies demonstrate that $\Delta \mathrm{FosB}$ is a potent in vitro substrate for CaMKII $\alpha\left(K_{\mathrm{M}}\right.$ $=5.7 \pm 2.0 \mu \mathrm{M} ; K_{\mathrm{CAT}}=2.3 \pm 0.3 \mathrm{~min}^{-1}$ ) with a stoichiometry of phosphorylation indicating at least three separate substrate sites $(2.27 \pm 0.07 \mathrm{~mol} / \mathrm{mol}$; Robison et al., 2013). In the same study, we identified $\mathrm{Ser}^{27}$ as one of the CaMKII substrate sites, a site previously shown to regulate the stability of $\Delta \mathrm{FosB}$ in vitro and in vivo (Ulery et al., 2006; Ulery-Reynolds et al., 2009). We demonstrated further that overexpression of constitutively active CaMKII promotes $\Delta$ FosB accumulation in vivo (Robison et al., 2013), indicating that $\operatorname{Ser}^{27}$ phosphorylation may be regulated by CaMKII in the brain. However, the identity and function of the other CaMKII phosphorylation sites within $\Delta$ FosB, and how they might regulate $\Delta$ FosB activity and drug responses, remain unknown. Here, we uncover two novel CaMKII phospho-sites within $\Delta$ FosB, $\mathrm{Thr}^{149}$, and $\mathrm{Thr}^{180}$ and demonstrate that phosphorylation of $\mathrm{Thr}^{149}$ is regulated in the brain by chronic cocaine, dramatically increases $\Delta$ FosB-mediated gene transcription, and promotes locomotor activation by cocaine in mice.

\section{Materials and Methods}

Animals. C57BL/6J male mice (The Jackson Laboratory), 7-8 weeks old and weighing 25-30 g, were habituated to the animal facility 1 week before use and maintained at $22-25^{\circ} \mathrm{C}$ on a $12 \mathrm{~h}$ light/dark cycle. All animals had access to food and water ad libitum. All experiments were conducted in accordance with the guidelines of the Institutional Animal Care and Use Committees at Icahn School of Medicine at Mount Sinai and Michigan State University.

Mass spectrometry. Standard peptides were designed to mimic the phospho or non-phospho forms of $\mathrm{Thr}^{149}{ }^{14} \mathrm{Thr}^{180}$, and Ser ${ }^{199} \Delta$ FosB. After synthesis and purification, each "heavy" idiotypic peptide was dissolved in 50/50 acetonitrile/water buffer and sent for amino acid analysis to determine absolute concentration of the synthetic peptide stock solution. Each heavy peptide was then directly infused into the 4000 QTRAP mass spectrometer (MS) at Yale's Keck Center to determine the best collision energy for MS/MS fragmentation and two to four multiple reaction monitoring (MRM) transitions. Next, the neat heavy peptides were subjected to LCMS on the 4000 QTRAP to ensure peptide separation. The instrument was run in the triple quadrupole mode, with Q1 set on the specific precursor $m / z$ value (Q1 is not scanning) and Q3 set to the specific $m / z$ value corresponding to a specific fragment of that peptide. In the MRM mode, a series of single reactions (precursor/fragment ion transitions where the collision energy is tuned to optimize the intensity of the fragment ions of interest) were measured sequentially, and the cycle (typically 1-2 s) was looped throughout the entire time of the HPLC separation. MRM transitions were determined from the MS/MS spectra of the existing peptides. Two transitions per peptide, corresponding to high-intensity fragment ions, were then selected and the collision energy optimized to maximize signal strength of MRM transitions using automation software. Peaks resulting from standard peptides and $\Delta F o s B$ samples from the brains of saline-treated or cocaine-treated mice were then compared to determine the absolute abundance of each peptide form in the samples. Data analysis on LC-MRM data is performed using AB MultiQuant 1.1 software.

Enrichment of $\Delta$ FosB from mouse brain. Mice were injected intraperitoneally with saline or cocaine $(15 \mathrm{mg} / \mathrm{kg})$ in their home cages once daily for $7 \mathrm{~d}$. Twenty four hours following the final injection, mice were decapitated without anesthesia to avoid effects of anesthetics on neuronal protein levels and phospho-states. Brains were serially sliced in a $1.0 \mathrm{~mm}$ matrix (Braintree Scientific) and NAc (ventral striatum) and dorsal striatum were removed in PBS containing protease (Roche) and phosphatase (Sigma-Aldrich) inhibitors using a 12 gauge punch and immediately frozen on dry ice. Tissue was homogenized in PBS with $0.2 \%$ Triton $\mathrm{X}-100$ and centrifuged at $10,000 \times g$ for $5 \mathrm{~min}$ at $4^{\circ} \mathrm{C}$ to remove insoluble proteins. The soluble fractions from 10 mice were combined and concentrated by dialysis against $0.1 \mathrm{~m}$ HEPES, pH7.4, and $500 \mathrm{~mm} \mathrm{NaCl}$. The resulting concentrated protein was separated by SDS-PAGE and bands from 32 to $40 \mathrm{kDa}$ were cut from the gel to enrich for $\Delta$ FosB $(35-37 \mathrm{kDa})$. Protein was extracted from the gel slices and subjected to mass spectroscopic analysis as described above.

DNA constructs. The luciferase reporter construct was $4 \times \mathrm{AP}-1 / \mathrm{RSV}-$ Luc, which consists of a promoter region of four AP-1 consensus sequences in tandem with a minimal RSV promoter, and a luciferase reporter gene under the control of this promoter (Ulery and Nestler, 2007). We used site-directed mutagenesis (Qiagen) to generate mutant constructs encoding $\Delta$ FosB with $\mathrm{Thr}^{149}$ or $\mathrm{Thr}^{180}$ converted to Asp (T149D and T180D) or to Ala (T149A and T180A) in a pcDNA3.1 backbone. WT or catalytically dead (Lys ${ }^{42}$ to Met) CaMKII was also expressed using the pcDNA3.1 backbone. All mutations were verified by dideoxysequencing.

Luciferase activity assays. Neuro2a cells (N2a; American Type Culture Collection) were cultured in EMEM (ATCC) supplemented with 10\% heat-inactivated fetal bovine serum (ATCC) in a $5 \% \mathrm{CO}_{2}$ humidified atmosphere at $37^{\circ} \mathrm{C}$. Cells were plated into 12 -well plates. Twenty-four hours later (when cells were $\sim 95 \%$ confluent) cells were transiently cotransfected with a combination of $4 \times$ AP-1/RSV-Luc plasmid and pcDNA3.1 plasmids (Life Technologies) containing WT or mutant $\Delta$ FosB and/or CaMKII $\alpha$ constructs using Effectene (Qiagen). A total of $200 \mathrm{ng}$ DNA was transfected per well. Approximately $48 \mathrm{~h}$ post transfection, cells were washed twice with $1 \mathrm{ml}$ PBS and whole-cell lysates were prepared using $180 \mu \mathrm{l}$ lysis buffer provided with ONE-Glo Luciferase Assay System (Promega). Fifty microliters of the lysate was removed for Western blot analysis. The remaining lysates were incubated on ice for 5 min and the luciferase activity (luminescence) present in each sample was assayed using the substrates and protocol included in the ONE-Glo Luciferase Assay System. The luminescence of each sample was detected in triplicate using Kodak autoradiography film and quantified using ImageJ software (NIH). Luminescence was normalized to total $\Delta$ FosB expression as assessed by Western blot.

Viral-mediated gene transfer. Mice were anesthetized with a mixture of ketamine $(100 \mathrm{mg} / \mathrm{kg})$ and xylazine $(10 \mathrm{mg} / \mathrm{kg})$ and prepared for stereotactic surgery. Thirty-three gauge syringe needles (Hamilton) were used to bilaterally infuse $0.5-1.0 \mu \mathrm{l}$ of virus into NAc at a rate of $0.1 \mu \mathrm{l} / \mathrm{min}$ at $1.6 \mathrm{~mm}$ anterior, $+1.5 \mathrm{~mm}$ lateral, and $4.4 \mathrm{~mm}$ ventral from bregma. We used bicistronic p1005 HSV vectors expressing GFP alone or GFP plus WT, T149D, or T149A $\Delta$ FosB. In this system, GFP expression is driven by a cytomegalovirus promoter, whereas the select gene of interest is driven by the IE4/5 promoter (Maze et al., 2010). In the locomotor experiment, viral expression was confirmed during tissue collection using fluorescence microscopy (Leica) to visualize GFP and ensure targeting of the NAc.

Locomotor activity assay. Locomotor activity was measured per published protocols (Lobo et al., 2010) with minor modifications. Activity was assessed in the $x$ - and $y$-planes for horizontal ambulation in a $75 \mathrm{~cm}^{2}$ chamber using EthoVision XT (Noldus). Twenty-four hours before undergoing surgery, mice were habituated to the locomotor chamber for 60 min with no injection. Three days after surgery (day 0 ) animals were injected intraperitoneally with saline and placed in locomotor chamber for $45 \mathrm{~min}$ at which time baseline locomotor was recorded. On days $4-8$ after surgery (days $1-5)$, animals were injected with cocaine $(3.75 \mathrm{mg} / \mathrm{kg})$ and analyzed for $45 \mathrm{~min}$.

Immunohistochemistry. Adult male mice were terminally anesthetized (15\% chloral hydrate) and transcardially perfused with PBS followed by $4 \%$ formalin. Brains were then postfixed overnight in formalin at $4^{\circ} \mathrm{C}$ and cryoprotected in $30 \%$ sucrose at $4^{\circ} \mathrm{C}$ until isotonic. Brains were sliced in $35 \mu \mathrm{m}$ sections on a freezing microtome and immunohistochemistry for $\Delta$ FosB expression was performed essentially as described previously (Perrotti et al., 2008). Briefly, slices were blocked for $1 \mathrm{~h}$ in $0.3 \%$ Triton 

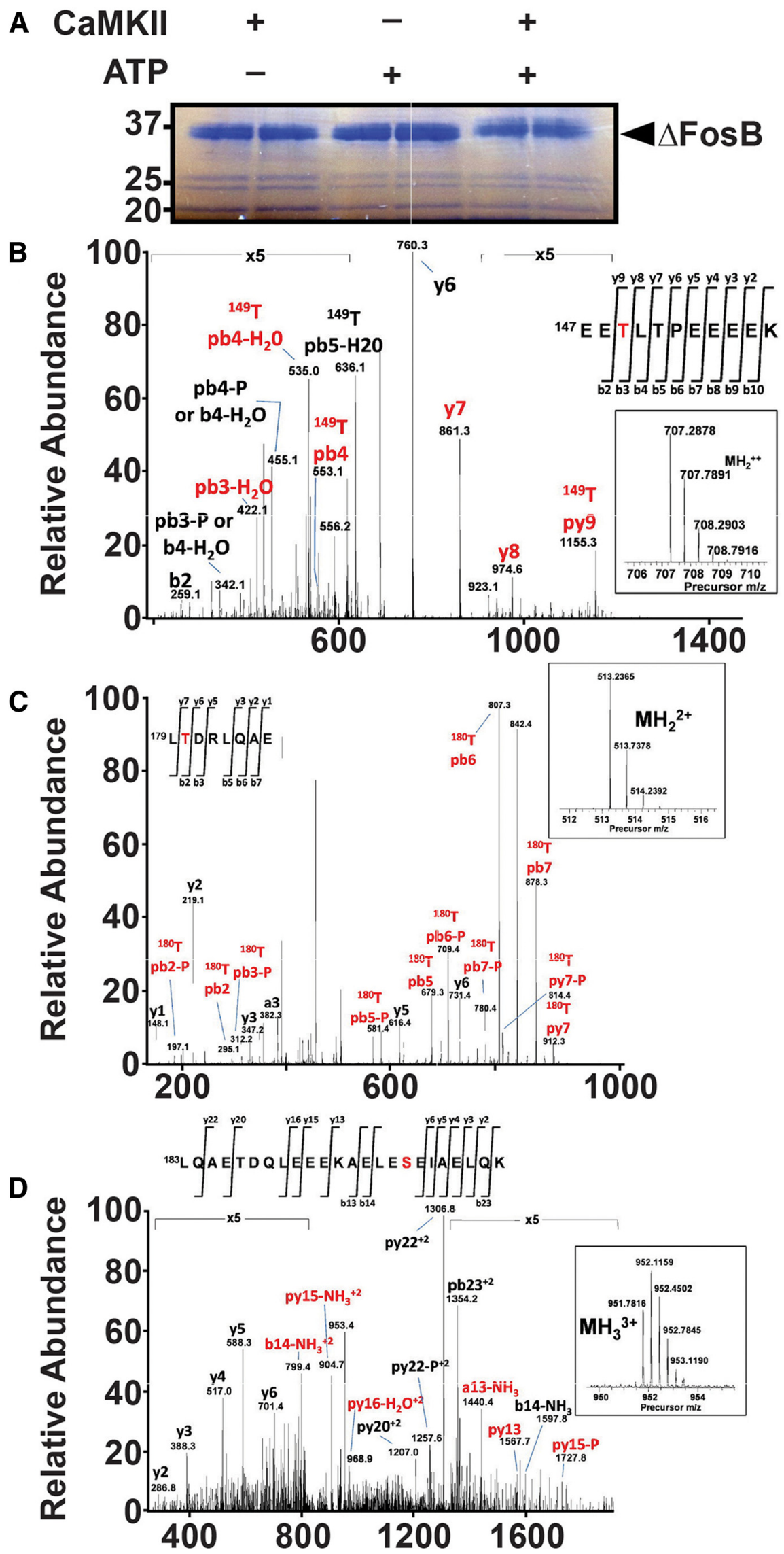

Figure 1. Identification of novel sites of $\triangle F$ FosB phosphorylation in vitro. $A$, Coomassie-stained SDS-PAGE gel with purified $\mathrm{His}_{6}-\Delta$ FosB exposed to CaMKII alone, ATP alone, or CaMKIl and ATP. Note the upward shift in electrophoretic mobility of $\Delta$ FosB
$\mathrm{X}-100$ and $3 \%$ normal goat serum at room temperature then incubated overnight at $4^{\circ} \mathrm{C}$ in $1 \%$ normal goat serum, $0.3 \%$ Triton $\mathrm{X}-100$, and pan-FosB antibody (Santa Cruz Biotechnology; sc-48, 1:1000). Sections were washed, placed for $1.5 \mathrm{~h}$ in a 1:200 dilution of Cy3conjugated goat anti-rabbit IgG (Millipore), and slices were mounted under glass coverslips for visualization on a confocal microscope (Axiovert 100; LSM 510 with META emission wavelengths of 488, 543, and $633 \mathrm{~nm}$; Zeiss). Images captured in both the red (FosB) and green (GFP) channels were quantified for intensity using ImageJ software (NIH).

Statistical analysis. All analysis was performed using Prism software (GraphPad). Student's $t$ tests were used for all pairwise comparisons (indicated in Results where the $t$ value is given), and one-way or two-way ANOVAs were used for all multiple comparisons (indicated in Results where the $F$ value is given), followed by Bonferroni or Tukey post hoc tests where appropriate.

\section{Results}

Novel CaMKII phospho-sites within $\triangle$ FosB

To identify novel CaMKII phospho-sites within $\Delta$ FosB, we performed in vitro phosphorylation of purified $\mathrm{His}_{6}-\Delta$ FosB with purified CaMKII $\alpha$ as previously described (Robison et al., 2013). Incubation of $\Delta$ FosB with CaMKII in the presence, but not absence, of ATP caused an increase in the apparent molecular weight of $\Delta$ FosB consistent with phosphorylation at multiple sites (Fig. 1A). MS analyses of these samples revealed phosphorylation of $\Delta$ FosB at $\mathrm{Thr}^{149}$, $\mathrm{Thr}^{180}$, and $\mathrm{Ser}^{199}$ (Fig. $1 B--D$ ), along with multiple additional sites (data not shown). All three of these sites are within the leucine-zipper domain of $\Delta$ FosB (Fig. $2 A$ ), and thus could regulate dimerization, DNA-binding, or transcriptional activation by the AP-1 complex.

Because both $\mathrm{Thr}^{149}$ and $\mathrm{Thr}^{180}$ were previously predicted as possible CaMKII phospho-sites by bioinformatics analysis (Ulery et al., 2006), and the CaMKII consensus phosphorylation sequence at both sites is perfectly conserved from zebrafish through humans (Fig. 2B), we focused on validation of these sites as bona fide CaMKII substrates. We generated labeled synthetic peptides mimicking the phosphoand non-phospho-states of $\mathrm{Thr}^{149}, \mathrm{Thr}^{180}$,

when exposed to CaMKII and ATP (black arrow). B-D, The precursor (inset) and fragment spectra of $\mathrm{TiO}_{2}$-enriched phosphopeptides detected from $\Delta$ FosB after in vitro phosphorylation by CaMKII. After using both trypsin digestion and enrichment of the phosphopeptide samples by $\mathrm{Ti}_{2}$, analysis reveals phosphorylation of $\operatorname{Thr}^{149}(\boldsymbol{B}), \operatorname{Thr}^{180}(\boldsymbol{C})$, and $\operatorname{Ser}^{199}(\boldsymbol{D})$. 
and Ser ${ }^{199}$ and then used known quantities of these peptides as standards in MRM analyses of $\Delta$ FosB before and after in vitro phosphorylation by CaMKII. Subsequent quantitation confirms that $\mathrm{Thr}^{149}$ and $\mathrm{Thr}^{180}$ are potent substrates for CaMKII, while Ser ${ }^{199}$ phosphorylation is entirely unaffected by coincubation with CaMKII (Fig. 2C).

\section{$\Delta$ FosB $\mathrm{Thr}^{149}$ phosphorylation in brain} is increased by chronic cocaine

Previous studies have demonstrated that $\Delta$ FosB is a phosphoprotein in the brain (Ulery et al., 2006). Therefore, we next sought to determine whether $\Delta \mathrm{FosB}$ is phosphorylated at $\mathrm{Thr}^{149}$ or $\mathrm{Thr}^{180}$ in the brain, and whether these phospho-sites are regulated by a behaviorally relevant stimulus, chronic cocaine exposure. Adult ( 8 weeks) male mice were administered 20 $\mathrm{mg} / \mathrm{kg}$ cocaine or saline vehicle intraperitoneally once per day for $7 \mathrm{~d}$. Twenty-four hours after the last injection striatum was harvested and proteins were homogenized in the presence of protease and phosphatase inhibitors, concentrated by dialysis, and proteins of $\sim 32-38 \mathrm{kDa}$ were purified by SDS-PAGE gel extraction. We then performed MRM analyses on the purified proteins using the same labeled peptides described above and observed peaks corresponding to phospho- $\mathrm{Thr}^{149}$ and phospho-Thr ${ }^{180}$ in striatal extracts (Fig. 3). Importantly, the amount of $\mathrm{Thr}^{149}$ phosphopeptide was significantly higher in the proteins purified from cocainetreated animals than in those from saline-treated controls (Fig. $\left.3 D ; t_{(4)}=3.203, p=0.0328\right)$. Levels of phospho- $\mathrm{Thr}^{180}$ were lower, and although there was a trend for an increase with cocaine, it was not significant (Fig. $3 H$ ). We therefore focused the remainder of our studies on $\mathrm{Thr}^{149}$ phosphorylation.

\section{$\Delta$ FosB $\mathrm{T}^{149}$ phosphorylation increases AP-1 transcriptional activity}

Because $\operatorname{Thr}^{149}$ is within the basic region of $\Delta \mathrm{FosB}$, which is important for DNA binding (Glover and Harrison, 1995; Fig. $2 A$ ), we hypothesized that $\mathrm{Thr}^{149}$ phosphorylation may regulate $\Delta$ FosB-mediated gene transcription. We constructed mutants of $\Delta$ FosB mimicking phosphorylation at $\mathrm{Thr}^{149}$ and $\mathrm{Thr}^{180}$ (T149D and T180D) and assayed their effects on gene transcription using an AP-1-luciferase reporter assay in Neuro2a cells. While T180D $\Delta$ FosB induces a twofold increase in AP-1-luciferase activity, which is comparable to WT $\Delta$ FosB's effect, T149D $\Delta$ FosB expression caused a dramatic 17 -fold increase in AP-1 luciferase activity (Fig. 4), much stronger than that of WT or T180D $\Delta$ FosB $\left(F_{(6,12)}\right.$ $=2.062 ; p<0.0001)$. Coexpressing WT CaMKII with WT $\Delta$ FosB increased induction of AP-1 activity to an extent similar to that observed with T149D $\Delta$ FosB, 15 -fold greater than WT $\Delta$ FosB alone. However, cotransfection with catalytically dead K42R CaMKII caused a much smaller though still significant increase, suggesting that CaMKII catalytic activity is the primary but not sole means by which it regulates $\Delta$ FosB transcriptional activity.
These data suggest that CaMKII-mediated phosphorylation of $\Delta$ FosB at $\mathrm{Thr}^{149}$ robustly increases AP-1 transcriptional activity of the protein.

\section{$\Delta$ FosB $T_{h r}{ }^{149}$ phosphorylation does not affect in vivo protein stability}

Previous data demonstrate that CaMKII overexpression can enhance the stability of $\Delta \mathrm{FosB}$ in mouse NAc in vivo (Robison et al., 2013), though the mechanism of this enhancement was not determined. Because phosphorylation of $\Delta \mathrm{FosB} \mathrm{Ser}^{27}$ is known to increase $\Delta$ FosB stability in vitro and in vivo (Ulery et al., 2006; Ulery-Reynolds et al., 2009), and $\operatorname{Ser}^{27}$ is a potent CaMKII substrate (Robison et al., 2013), we hypothesized that CaMKII phosphorylation of $\mathrm{Ser}^{27}$ was responsible for this enhancement of stability. Nevertheless, we sought to determine whether $\mathrm{Thr}^{149}$ phosphorylation could also regulate $\Delta$ FosB stability in mouse brain. We constructed herpes simplex virus (HSV) vectors that express GFP along with WT, phospho-absent (T149A), or phosphomimetic (T149D) $\triangle F$ FosB and injected them into the NAc of adult male mice (Fig. 5). Animals were analyzed 3, 7, or $14 \mathrm{~d}$ after virus injection, and $\triangle \mathrm{FosB}$ expression levels were assessed by immunofluorescence and quantitative image analysis (Fig. 6A). No significant difference in $\Delta$ FosB expression was found between WT $\Delta$ FosB and either mutant at any of the three time points assessed (Fig. 6B). Thus, unlike $\mathrm{Se}^{27}$, $\mathrm{Thr}^{149}$ phosphorylation does not alter $\Delta$ FosB stability in vivo. 


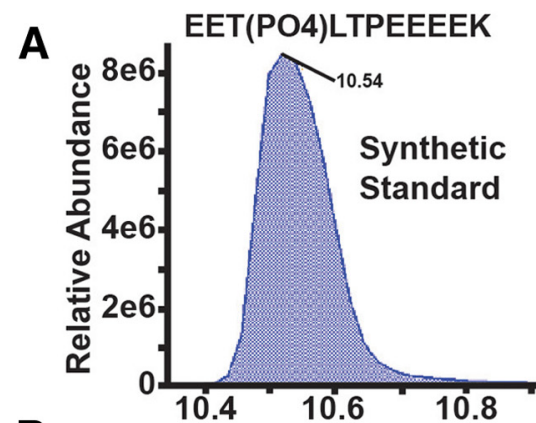

B

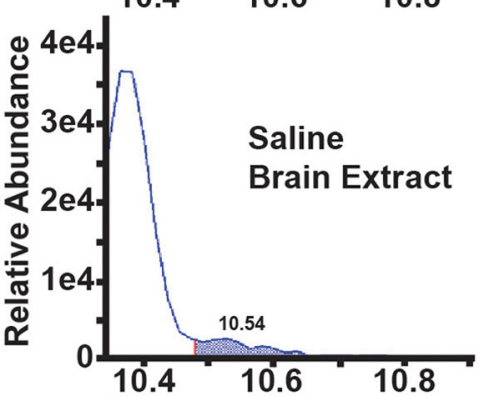

C
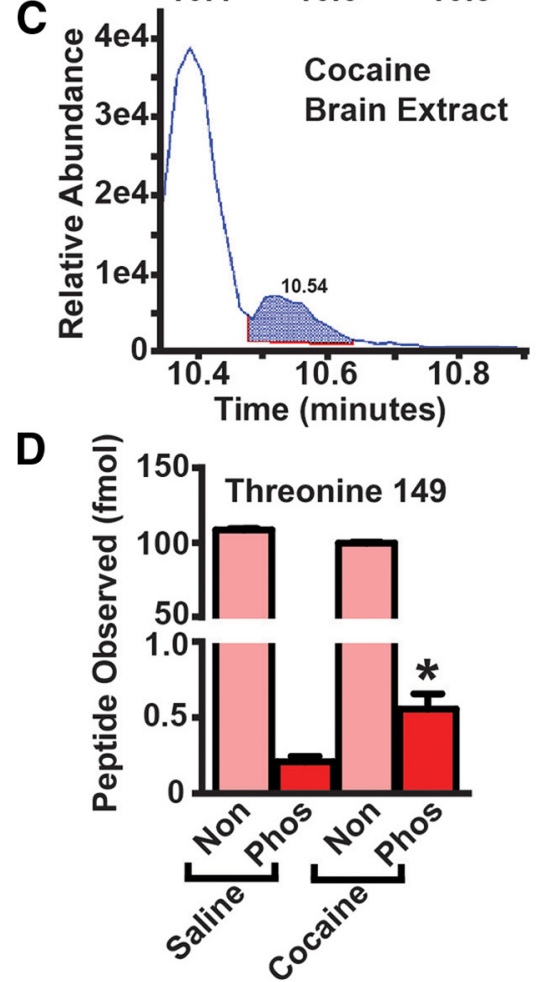

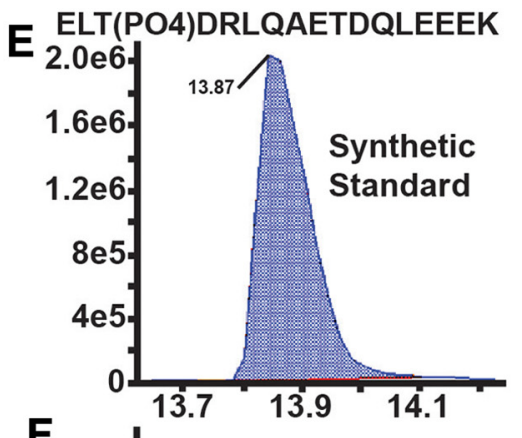

$\mathbf{F}$

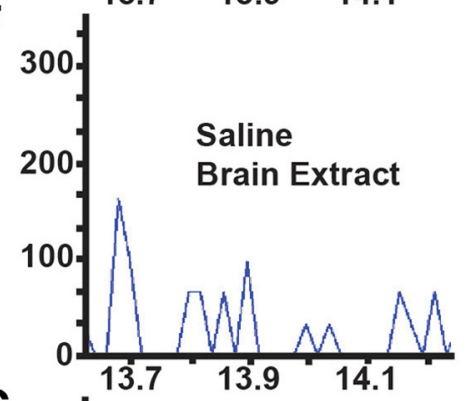

G

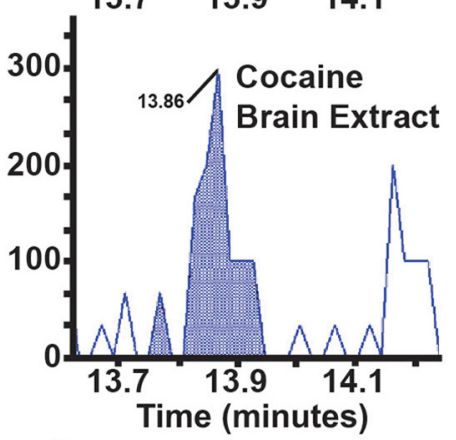

H

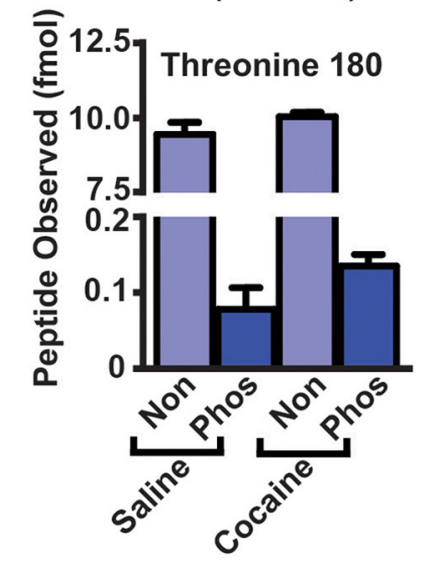

Figure 3. Phosphorylation of $\Delta \mathrm{FosB} \mathrm{Thr}^{149}$ but not $\mathrm{Thr}^{180}$ in mouse brain is increased by chronic cocaine. $A$, MRM analysis peak for synthetic peptide mimicking phospho-Thr ${ }^{149}$. MRM analysis of striatal extracts from saline-treated $(\boldsymbol{B})$ and cocaine-treated $(\boldsymbol{C})$ mice reveals a peak corresponding to the phospho-Thr ${ }^{149}$ peptide. $\boldsymbol{D}$, Quantitation of MRM analysis demonstrating a significant increase in the phospho-Thr ${ }^{149}$ peptide in the cocaine sample compared with the control sample. $\boldsymbol{E}$, MRM analysis peak for synthetic peptide mimicking phospho-Thr ${ }^{180}$. MRM analysis of striatal extracts from saline-treated $(\boldsymbol{F})$ and cocaine-treated $(\boldsymbol{G})$ mice reveals a peak corresponding to the phospho-Thr ${ }^{180}$ peptide. $\boldsymbol{H}$, Quantitation of MRM analysis demonstrating no significant difference in the phospho-Thr ${ }^{180}$ peptide in the cocaine sample compared with the control sample. ( $n=3$ measurements per group; error bars represent SEM; ${ }^{*} p<0.05$ compared with saline phosphopeptide).

\section{$\Delta$ FosB Thr $^{149}$ phosphorylation mediates the psychomotor effects of cocaine}

Viral and transgenic $\Delta$ FosB overexpression enhances the locomotor-activating effects of cocaine, whereas viral blockade of endogenous FosB transcriptional activity reduces cocaine's locomotor effects (Kelz et al., 1999; Grueter et al., 2013; Robison et al., 2013). We used HSV-mediated overexpression of WT or mutant
$\Delta$ FosB to determine whether $\mathrm{Thr}^{149}$ phosphorylation affects the ability of $\Delta$ FosB to regulate locomotor responses to cocaine. None of the $\Delta$ FosB vectors had a significant effect on baseline locomotor activity (Fig. $7 A$ ). We used a low dose of cocaine $(3.75 \mathrm{mg} / \mathrm{kg})$ over $5 \mathrm{~d}$ that does not normally elicit locomotor sensitization (Grueter et al., 2013) to maximize chances of seeing increased behavioral responses. We found a significant effect of virus $\left(F_{(3,113)}=3.373 ; p<0.0005\right)$ and day $\left(F_{(2,113)}=19.08 ; p<0.0001\right)$ on locomotor activity. As expected, animals overexpressing GFP alone showed no locomotor activation to initial or repeated low doses of cocaine, while animals expressing WT $\Delta$ FosB displayed increased locomotor activity only after repeated cocaine administration (post hoc analysis, day 5 vs day $1 ; t_{(17)}=3.098 ; p=0.0065$; Fig. 7B). Animals expressing T149D $\Delta$ FosB exhibited increased locomotor activity to cocaine following the first administration (post hoc analysis, day 1 vs day 0; $t_{(24)}=4.137 ; p<0.0005$; Fig. $\left.7 B\right)$, which did not increase further with continued exposure (post hoc analysis, day 1 vs day 5; $t_{(22)}=0.384 ; p=0.705$; Fig. $7 B$ ). In contrast, animals expressing T149A $\Delta$ FosB did not sensitize to cocaine at all, thus appearing phenotypically similar to GFPalone controls. These data indicate that $\Delta$ FosB $\mathrm{Thr}^{149}$ phosphorylation can confer an increased initial sensitivity to the locomotor-activating effects of low-dose cocaine, which mimics that seen after repeated administration of a low dose, and is necessary for $\Delta$ FosB-mediated increases in locomotor sensitization during repeated administration.

To determine whether $\mathrm{Thr}^{149}$ phosphorylation is also necessary for the locomotor sensitization that typically occurs in response to a higher dose of cocaine, we administered $5 \mathrm{~d}$ of $7.5 \mathrm{mg} / \mathrm{kg}$ cocaine to mice with HSV-mediated NAc overexpression of GFP alone, WT $\Delta$ FosB, or T149A $\Delta$ FosB (Fig. 8). As before, these mice had no difference in baseline locomotor response to a saline injection (Fig. $8 A)$, but with cocaine we found a significant effect of both virus $\left(F_{(2,69)}=4.092\right.$; $p<0.05)$ and day $\left(F_{(2,69)}=48.88 ; p<\right.$ $0.0001)$. Control (GFP-alone) mice exhibited a locomotor response to acute cocaine that was greater than the saline response (post hoc analysis, day 1 vs day $0 ; t_{(16)}=2.123 ; p<0.05$; Fig. $8 B$ ) and exhibited locomotor sensitization over time (post hoc analysis, day 1 vs day $5 ; t_{(16)}=2.445 ; p<0.05$; Fig. $8 B$ ). Animals expressing WT $\Delta$ FosB in NAc also exhibited a significant acute response to cocaine (post hoc analysis, day 1 vs day $0 ; t_{(18)}=5.097 ; p<0.0001$; Fig. $8 B$ ) and exhibited locomotor sensitization over time (post 


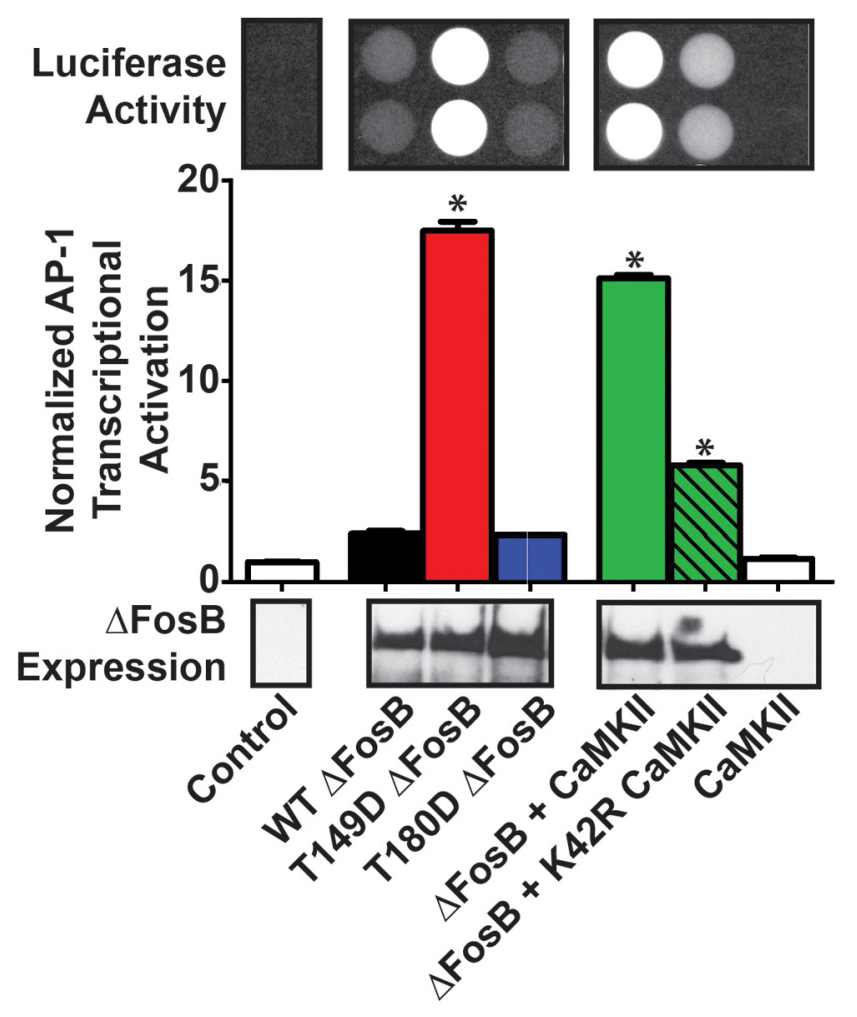

Figure 4. Thr ${ }^{149}$ controls $\Delta$ FosB-mediated transcriptional activity. Luciferase reporter assay (top) in Neuro2A cells demonstrates that $T h r{ }^{149}$ phosphomimetic mutation of $\Delta$ FosB increases transcriptional activation of a 4xAP-1 reporter construct $>7$-fold compared with WT $\Delta$ FosB or $\triangle$ FosB-T180D, both of which induce AP-1 activity $\sim 2$-fold. Cotransfection of WT CaMKII with WT $\Delta$ FosB results in a similar increase as $\Delta$ FosB-T149D, while the catalytically dead K42R CaMKII mutant, caused only a twofold change. Western blot (bottom) shows equal expression of all $\Delta$ FosB constructs. ( $n=3$ wells per group; error bars represent SEM; ${ }^{*} p<0.0001$ compared with WT $\Delta$ FosB).

hoc analysis, day 1 vs day $5 ; t_{(16)}=2.977 ; p<0.01$; Fig. $8 B$ ). However, although animals expressing T149A $\Delta$ FosB in NAc had an acute response to cocaine ( post hoc analysis, day 1 vs day $0 ; t_{(13)}$ $=4.249 ; p<0.001$; Fig. $8 B$ ), they exhibited no sensitization of locomotor response with repeated administration (post hoc analysis, day 1 vs day $5 ; t_{(13)}=0.0091 ; p=0.99$; Fig. $8 B$ ). Although this lack of sensitization in the T149A $\Delta$ FosB animals appears to be driven by the acute response to cocaine on day 1, post hoc test reveals no significant difference between GFP alone and T149A $\Delta$ FosB in day 1 response to cocaine $\left(t_{(14)}=1.965 ; p=0.069\right)$. Thus, the data suggest that $\Delta$ FosB Thr $^{149}$ phosphorylation is necessary for the locomotor sensitization to repeated cocaine observed in control animals.

\section{Discussion}

Here, we identify novel sites of CaMKII-mediated phosphorylation of $\Delta$ FosB in vitro; demonstrate that phosphorylation of one of these sites, $\mathrm{Thr}^{149}$, is increased in striatum in vivo by chronic cocaine; and show that this site regulates $\Delta$ FosB-induced transcriptional activity and locomotor activation to cocaine. This novel mechanism further solidifies the NAc-specific connection between CaMKII and $\Delta$ FosB in regulating drug responses (Robison et al., 2013, 2014), and suggests that exploration of possible roles for this molecular pathway in other brain regions and in regulation of other cellular and behavioral functions is an important focus for future studies.

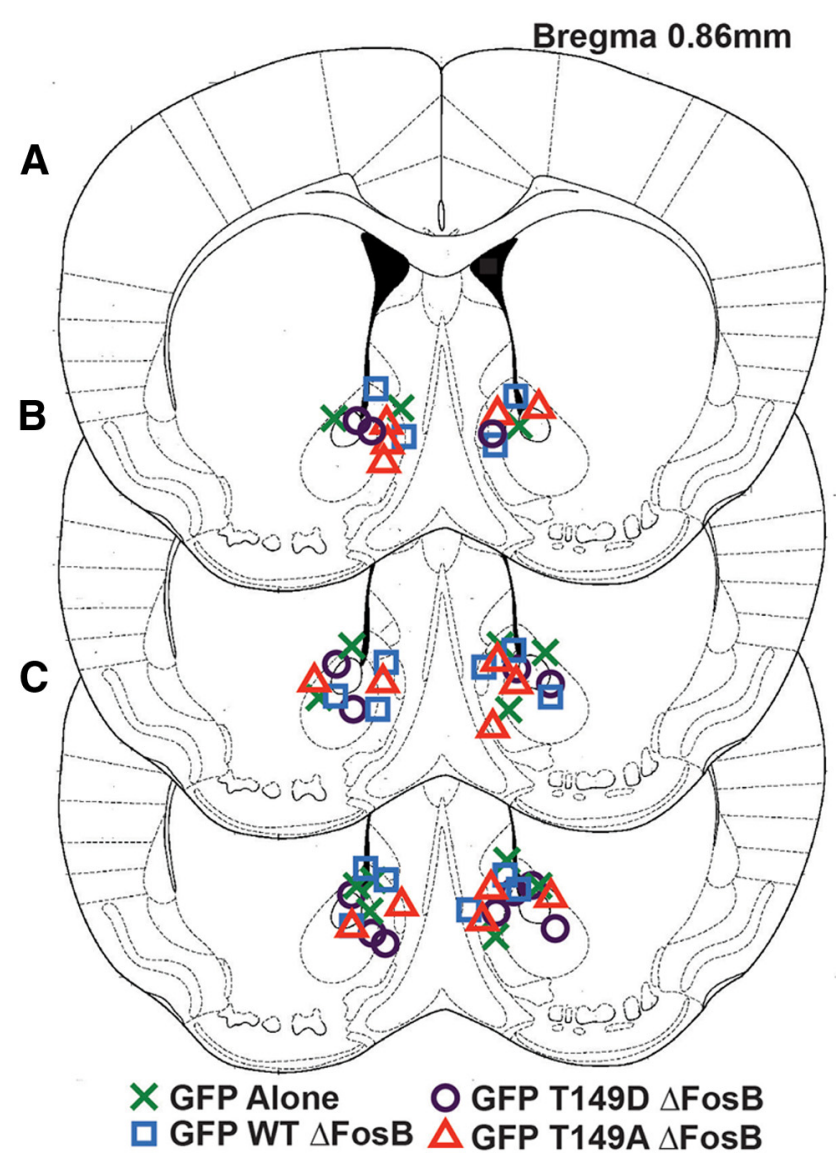

Figure 5. Injection sites for HSV-mediated $\Delta$ FosB mutant overexpression studies. Adult male mice were stereotactically injected bilaterally in the NAc with HSVs expressing GFP alone or GFP plus WT $\Delta$ FosB, T149D $\Delta$ FosB, or T149A $\Delta$ FosB. Animals were allowed to recover and then analyzed $3 \mathrm{~d}(\boldsymbol{A}), 7 \mathrm{~d}(\boldsymbol{B})$, or $14 \mathrm{~d}(\boldsymbol{C})$ after HSV injection. Symbols mark center mass for each injection; viral spread was typically $1 \mathrm{~mm}^{3}$ as observed previously (Robison et al., 2013).

Although a role for NAc CaMKII expression and activity has been established in several contexts, including behavioral responses to cocaine (Pierce et al., 1998; Wang et al., 2010; Robison et al., 2013), amphetamine (Loweth et al., 2008, 2010, 2013), and antidepressants (Robison et al., 2014), the mechanism of its action in NAc has not been completely delineated. CaMKII drives surface expression of AMPA receptors (Hayashi et al., 2000), a phenomenon associated in NAc with behavioral sensitization to cocaine (Boudreau and Wolf, 2005). More recently, a detailed mechanism for CaMKII regulation of AMPA receptor surface expression has emerged involving CaMKII phosphorylation of stargazin (Stg), which modulates the ability of Stg to mediate recruitment of AMPA receptors to the postsynaptic density (PSD) by the structural proteins PSD-95 and PSD-93 (Hell, 2014). Because locomotor sensitization is dependent on CaMKII activity and AMPA receptor function (Pierce et al., 1996, 1998), and because behavioral responses to AMPA receptor activation in NAc are enhanced by CaMKII $\alpha$ overexpression (Singer et al., 2010), it seems likely that the behavioral effects of CaMKII on cocaine responses are due at least in part to modulation of AMPA receptor function. Moreover, CaMKII activity in the NAc is required for reinstatement of cocaine seeking in selfadministration assays, and this process results in increased phosphorylation of the AMPA receptor GluA1 at $\mathrm{Ser}^{831}$ and is blocked by a viral vector that impairs the transport of GluA1-containing AMPA receptors to the synaptic membrane (Anderson et al., 
A

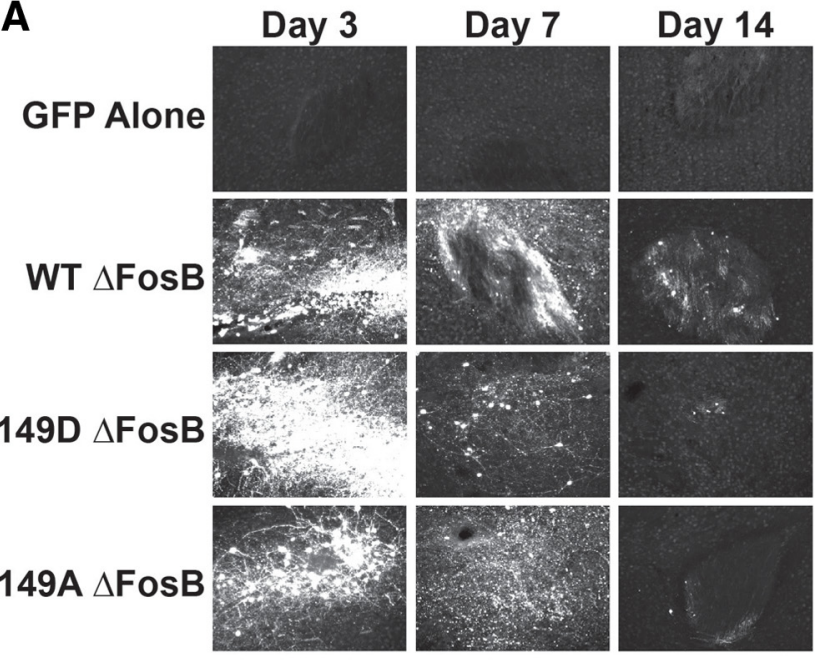

B

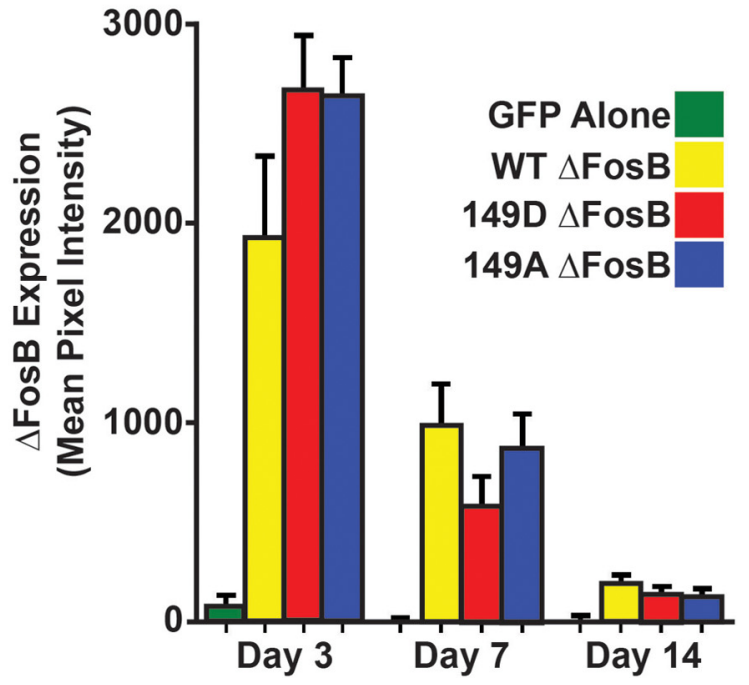

Figure 6. Thr ${ }^{149}$ phosphorylation does not affect $\Delta$ FosB stability in vivo. A, Immunohistochemistry reveals $\triangle$ FosB expression in the mouse NAc 3,7 , and $14 \mathrm{~d}$ after injection of HSV-GFP or HSV-GFP-WT $\Delta$ FosB,-T149D $\Delta$ FosB, or-T149A $\Delta$ FosB. B, Quantitative image analysis shows that all constructs express $\Delta$ FosB to a similar extent compared with GFP alone control, and that there is no difference in the persistence of $\Delta$ FosB expression over time between any of the constructs ( $n=4-8$ injections per group error bars represent SEM).

2008). Since $\Delta$ FosB regulates AMPA receptor subunit expression in multiple contexts including chronic cocaine exposure (Kelz et al., 1999; Vialou et al., 2010), we hypothesize that CaMKII mediates complex changes in AMPA receptor function at NAc synapses both by direct modulation of receptor conductance and incorporation at PSDs and by phosphorylating $\triangle \mathrm{FosB}$ to control receptor expression and subunit composition. However, AMPA receptor plasticity in NAc following cocaine self-administration is complicated and differs depending on route of administration, time of abstinence, and re-exposure (Wolf and Ferrario, 2010; Pierce and Wolf, 2013), and integrating these changes with the amount and location of $\Delta$ FosB expression will be a challenge going forward.

$\Delta$ FosB Ser $^{27}$ phosphorylation regulates protein stability (Ulery-Reynolds et al., 2009), and CaMKII phosphorylates $\Delta$ FosB at $\operatorname{Ser}^{27}$ and regulates $\Delta$ FosB stability in the brain (Robison et al., 2013). However, $\operatorname{Ser}^{27}$ phosphorylation also regulates $\Delta$ FosB transcriptional activity, as mutation of $\operatorname{Ser}^{27}$ to Ala reduces $\Delta$ FosB-mediated AP-1-luciferase activity (Ulery and Nestler, 2007). In those earlier studies, we found that mutation of
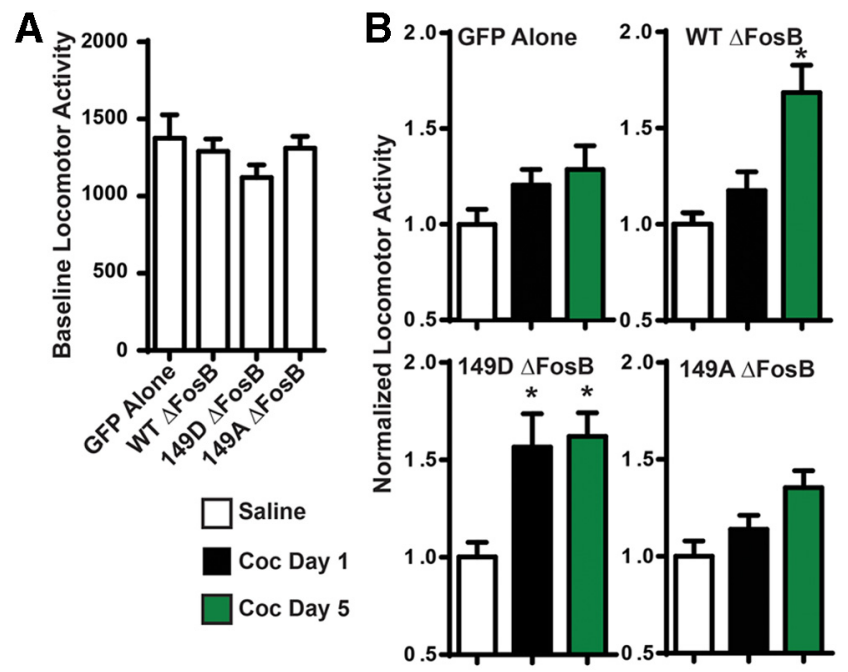

Figure 7. $\Delta$ FosB Thr $^{149}$ phosphorylation drives cocaine-induced psychomotor activity. $\boldsymbol{A}$, Baseline locomotor activity is unaffected by HSV-GFP-WT $\Delta$ FosB, -T149D $\Delta$ FosB, or -T149A $\triangle$ FosB in mouse $N A c$. $\boldsymbol{B}$, Normalized locomotor activity after intraperitoneal injection of saline or on day 1 or day 5 of five daily cocaine $(3.5 \mathrm{mg} / \mathrm{kg})$ injections in mice from $A$. Cocaine elicited significant locomotor activity compared with saline only on day 5 in animals expressing WT $\Delta$ FosB, but on both days 1 and 5 in animals expressing T149D $\Delta$ FosB. $(n=10$ animals per group; error bars represent SEM; ${ }^{*} p<0.05$ compared with saline).
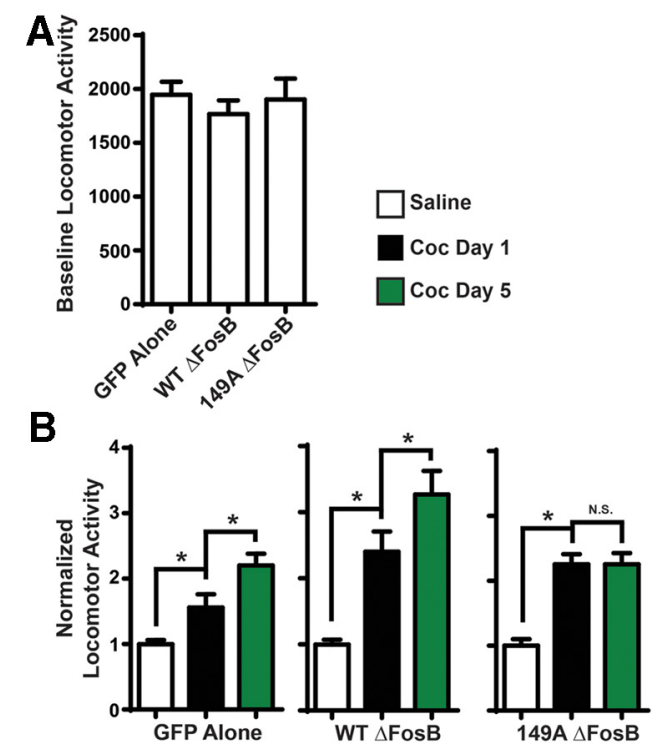

Figure 8. $\quad \Delta \mathrm{FosB}^{\mathrm{T}} \mathrm{Tr}^{149}$ phosphorylation is required for cocaine-induced psychomotor sensitization. $A$, Baseline locomotor activity is unaffected by HSV-GFP-WT $\Delta$ FosB or -T149A $\Delta$ FosB in mouse NAc. $B$, Normalized locomotor activity after intraperitoneal injection of saline or on day 1 or day 5 of five daily cocaine $(7.5 \mathrm{mg} / \mathrm{kg})$ injections in mice from $\boldsymbol{A}$. Cocaine elicited significant locomotor activity compared with saline on day 1 in all animals, but only animals expressing GFP or WT $\Delta$ FosB showed a sensitized response to cocaine on day 5 compared with day 1. ( $n=7-10$ animals per group; error bars represent SEM; ${ }^{*} p<0.05$ compared with saline).

$\mathrm{Ser}^{27}$ to Asp has no effect on $\Delta$ FosB's transactivation potential. Moreover, the $\operatorname{Ser}^{27}$ effect is specific to $\Delta \mathrm{FosB}$, as the same S27A mutation in the context of full-length FosB has no significant effect. Because the transactivation potential of WT $\Delta$ FosB is less than that of full-length FosB under the same conditions (Ulery and Nestler, 2007), specific regulation of $\Delta$ FosB's transactivation potential by $\mathrm{Ser}^{27}$ and $\mathrm{Thr}^{149}$ phosphorylation may add a level of control required for long-lasting $\Delta$ FosB to function properly, but 
not necessary for the proper functioning of full-length FosB, whose transient expression may provide all of the required temporal specificity. Future studies will determine whether $\mathrm{Thr}^{149}$ phosphorylation regulates function of full-length FosB.

The location of $\mathrm{Thr}^{149}$, adjacent to the DNA-binding domain and very close to the transactivation domain (Fig. 2A; for review, see Morgan and Curran, 1995), suggests that it might regulate DNA binding or dimerization, either with Jun proteins or homodimerization (Jorissen et al., 2007), to directly alter affinity for DNA or the specificity of DNA binding sites. However, because $\Delta$ FosB is missing much of the transactivation (and degron) domains present in full-length FosB (Carle et al., 2007), the exact mechanisms of $\Delta$ FosB transactivation are unknown. Thus, it is also possible that $\mathrm{Thr}^{149}$ phosphorylation could affect transactivation potential directly, by allosteric alteration of protein-protein interactions, or indirectly by alteration of secondary or tertiary protein structure to affect the conformation of other regions of $\Delta$ FosB important for protein-protein interactions. Because T149D mutation enhances the ability of $\Delta \mathrm{FosB}$ to regulate the locomotor-activating effects of cocaine (Fig. 7), it is clear that $\mathrm{Thr}^{149}$ phosphorylation must regulate the extent of $\Delta$ FosBmediated transactivation of target genes or the specific subset of genes targeted in vivo. Understanding the specific genes transcriptionally altered by $\Delta$ FosB $\mathrm{Thr}^{149}$ phosphorylation, and the extent of their induction, will require the generation of novel tools, including transgenic mice with point mutations at $\mathrm{Thr}^{149}$. Such an understanding may uncover previously unstudied genes important for the effects of cocaine, and thus provide novel targets for therapeutic intervention in addiction.

\section{References}

Anderson SM, Famous KR, Sadri-Vakili G, Kumaresan V, Schmidt HD, Bass CE, Terwilliger EF, Cha JH, Pierce RC (2008) CaMKII: a biochemical bridge linking accumbens dopamine and glutamate systems in cocaine seeking. Nat Neurosci 11:344-353. CrossRef Medline

Been LE, Hedges VL, Vialou V, Nestler EJ, Meisel RL (2013) DeltaJunD overexpression in the nucleus accumbens prevents sexual reward in female Syrian hamsters. Genes Brain Behav 12:666-672. CrossRef Medline

Boudreau AC, Wolf ME (2005) Behavioral sensitization to cocaine is associated with increased AMPA receptor surface expression in the nucleus accumbens. J Neurosci 25:9144-9151. CrossRef Medline

Carle TL, Ohnishi YN, Ohnishi YH, Alibhai IN, Wilkinson MB, Kumar A, Nestler EJ (2007) Proteasome-dependent and -independent mechanisms for FosB destabilization: identification of FosB degron domains and implications for DeltaFosB stability. Eur J Neurosci 25:3009-3019. CrossRef Medline

Colby CR, Whisler K, Steffen C, Nestler EJ, Self DW (2003) Striatal cell type-specific overexpression of DeltaFosB enhances incentive for cocaine. J Neurosci 23:2488-2493. Medline

Glover JN, Harrison SC (1995) Crystal structure of the heterodimeric bZIP transcription factor c-Fos-c-Jun bound to DNA. Nature 373:257-261. CrossRef Medline

Grueter BA, Robison AJ, Neve RL, Nestler EJ, Malenka RC (2013) FosB differentially modulates nucleus accumbens direct and indirect pathway function. Proc Natl Acad Sci U S A 110:1923-1928. CrossRef Medline

Hayashi Y, Shi SH, Esteban JA, Piccini A, Poncer JC, Malinow R (2000) Driving AMPA receptors into synapses by LTP and CaMKII: requirement for GluR1 and PDZ domain interaction. Science 287:2262-2267. CrossRef Medline

Hell JW (2014) CaMKII: claiming center stage in postsynaptic function and organization. Neuron 81:249-265. CrossRef Medline

Jorissen HJ, Ulery PG, Henry L, Gourneni S, Nestler EJ, Rudenko G (2007) Dimerization and DNA-binding properties of the transcription factor DeltaFosB. Biochemistry 46:8360-8372. CrossRef Medline

Kelz MB, Chen J, Carlezon WA Jr, Whisler K, Gilden L, Beckmann AM, Steffen C, Zhang YJ, Marotti L, Self DW, Tkatch T, Baranauskas G, Surmeier DJ, Neve RL, Duman RS, Picciotto MR, Nestler EJ (1999) Expres- sion of the transcription factor deltaFosB in the brain controls sensitivity to cocaine. Nature 401:272-276. CrossRef Medline

Lobo MK, Covington HE 3rd, Chaudhury D, Friedman AK, Sun H, DamezWerno D, Dietz DM, Zaman S, Koo JW, Kennedy PJ, Mouzon E, Mogri M, Neve RL, Deisseroth K, Han MH, Nestler EJ (2010) Cell type-specific loss of BDNF signaling mimics optogenetic control of cocaine reward. Science 330:385-390. CrossRef Medline

Loweth JA, Baker LK, Guptaa T, Guillory AM, Vezina P (2008) Inhibition of CaMKII in the nucleus accumbens shell decreases enhanced amphetamine intake in sensitized rats. Neurosci Lett 444:157-160. CrossRef Medline

Loweth JA, Singer BF, Baker LK, Wilke G, Inamine H, Bubula N, Alexander JK, Carlezon WA Jr, Neve RL, Vezina P (2010) Transient overexpression of alpha-Ca2+/calmodulin-dependent protein kinase II in the nucleus accumbens shell enhances behavioral responding to amphetamine. J Neurosci 30:939-949. CrossRef Medline

Loweth JA, Li D, Cortright JJ, Wilke G, Jeyifous O, Neve RL, Bayer KU, Vezina P (2013) Persistent reversal of enhanced amphetamine intake by transient CaMKII inhibition. J Neurosci 33:1411-1416. CrossRef Medline

Maze I, Schaefer A, Dietz D, Covington HE 3rd, Sampath SC, Tarakhovsky A, Greengard P, Nestler EJ (2010) G9a regulates cocaine-induced behavioral and transcriptional plasticity in a cell-type specific manner. Soc Neurosci Abstr 36:574.7.

McClung CA, Nestler EJ (2003) Regulation of gene expression and cocaine reward by CREB and DeltaFosB. Nat Neurosci 6:1208-1215. CrossRef Medline

Morgan JI, Curran T (1995) Immediate-early genes: ten years on. Trends Neurosci 18:66-67. CrossRef Medline

Nestler EJ (2008) Review. Transcriptional mechanisms of addiction: role of DeltaFosB. Philos Trans R Soc Lond B Biol Sci 363:3245-3255. CrossRef Medline

Peakman MC, Colby C, Perrotti LI, Tekumalla P, Carle T, Ulery P, Chao J, Duman C, Steffen C, Monteggia L, Allen MR, Stock JL, Duman RS, McNeish JD, Barrot M, Self DW, Nestler EJ, Schaeffer E (2003) Inducible, brain region-specific expression of a dominant negative mutant of c-Jun in transgenic mice decreases sensitivity to cocaine. Brain Res 970:73-86. CrossRef Medline

Perrotti LI, Weaver RR, Robison B, Renthal W, Maze I, Yazdani S, Elmore RG, Knapp DJ, Selley DE, Martin BR, Sim-Selley L, Bachtell RK, Self DW, Nestler EJ (2008) Distinct patterns of DeltaFosB induction in brain by drugs of abuse. Synapse 62:358-369. CrossRef Medline

Pierce RC, Wolf ME (2013) Psychostimulant-induced neuroadaptations in nucleus accumbens AMPA receptor transmission. Cold Spring Harb Perspect Med 3:a012021. CrossRef Medline

Pierce RC, Bell K, Duffy P, Kalivas PW (1996) Repeated cocaine augments excitatory amino acid transmission in the nucleus accumbens only in rats having developed behavioral sensitization. J Neurosci 16:1550-1560. Medline

Pierce RC, Quick EA, Reeder DC, Morgan ZR, Kalivas PW (1998) Calcium-mediated second messengers modulate the expression of behavioral sensitization to cocaine. J Pharmacol Exp Ther 286:11711176. Medline

Pitchers KK, Frohmader KS, Vialou V, Mouzon E, Nestler EJ, Lehman MN, Coolen LM (2010) DeltaFosB in the nucleus accumbens is critical for reinforcing effects of sexual reward. Genes Brain Behav 9:831-840. CrossRef Medline

Pitchers KK, Vialou V, Nestler EJ, Laviolette SR, Lehman MN, Coolen LM (2013) Natural and drug rewards act on common neural plasticity mechanisms with DeltaFosB as a key mediator. J Neurosci 33:3434-3442. CrossRef Medline

Robison AJ, Nestler EJ (2011) Transcriptional and epigenetic mechanisms of addiction. Nat Rev Neurosci 12:623-637. CrossRef Medline

Robison AJ, Vialou V, Sun HS, Labonte B, A Golden S, Dias C, Turecki G, Tamminga C, Russo S, Mazei-Robison M, Nestler EJ (2014) Fluoxetine epigenetically alters the CaMKIIalpha promoter in nucleus accumbens to regulate DeltaFosB binding and antidepressant effects. Neuropsychopharmacology 39:1178-1186. Medline

Robison AJ, Vialou V, Mazei-Robison M, Feng J, Kourrich S, Collins M, Wee S, Koob G, Turecki G, Neve R, Thomas M, Nestler EJ (2013) Behavioral and structural responses to chronic cocaine require a feedforward loop involving DeltaFosB and calcium/calmodulin-dependent protein kinase ii in the nucleus accumbens shell. J Neurosci 33:4295-4307. CrossRef Medline 
Singer BF, Loweth JA, Neve RL, Vezina P (2010) Transient viral-mediated overexpression of alpha-calcium/calmodulin-dependent protein kinase II in the nucleus accumbens shell leads to long-lasting functional upregulation of alpha-amino-3-hydroxyl-5-methyl-4-isoxazole-propionate receptors: dopamine type-1 receptor and protein kinase A dependence. Eur J Neurosci 31:1243-1251. CrossRef Medline

Ulery PG, Nestler EJ (2007) Regulation of DeltaFosB transcriptional activity by Ser27 phosphorylation. Eur J Neurosci 25:224-230. CrossRef Medline

Ulery PG, Rudenko G, Nestler EJ (2006) Regulation of DeltaFosB stability by phosphorylation. J Neurosci 26:5131-5142. CrossRef Medline

Ulery-Reynolds PG, Castillo MA, Vialou V, Russo SJ, Nestler EJ (2009) Phosphorylation of DeltaFosB mediates its stability in vivo. Neuroscience 158:369-372. CrossRef Medline

Vialou V Robison AJ, Laplant QC, Covington HE 3rd, Dietz DM, Ohnishi YN, Mouzon E, Rush AJ 3rd, Watts EL, Wallace DL, Iñiguez SD, Ohnishi
YH, Steiner MA, Warren BL, Krishnan V, Bolaños CA, Neve RL, Ghose S, Berton O, Tamminga CA, et al. (2010) DeltaFosB in brain reward circuits mediates resilience to stress and antidepressant responses. Nat Neurosci 13:745-752. CrossRef Medline

Wang L, Lv Z, Hu Z, Sheng J, Hui B, Sun J, Ma L (2010) Chronic cocaineinduced $\mathrm{H} 3$ acetylation and transcriptional activation of CaMKIIalpha in the nucleus accumbens is critical for motivation for drug reinforcement. Neuropsychopharmacology 35:913-928. CrossRef Medline

Wolf ME, Ferrario CR (2010) AMPA receptor plasticity in the nucleus accumbens after repeated exposure to cocaine. Neurosci Biobehav Rev 35: 185-211. CrossRef Medline

Zachariou V, Bolanos CA, Selley DE, Theobald D, Cassidy MP, Kelz MB, Shaw-Lutchman T, Berton O, Sim-Selley LJ, Dileone RJ, Kumar A, Nestler EJ (2006) An essential role for DeltaFosB in the nucleus accumbens in morphine action. Nat Neurosci 9:205-211. CrossRef Medline 